\title{
Organizational Culture and Organization Based Self- Esteem as Predictors of Spirit at work
}

\author{
Zeynep Merve Ünal \\ Marmara University, Turkey \\ Tülay Turgut \\ Marmara University, Turkey
}

\section{Introduction}

The past several years have witnessed explosion of interest in spirituality at workplace among practitioners and scholars. As Benefiel (2003) discussed "spirituality and management, once thought incompatible, have in the past decade fallen in love" (p. 383). Laabs (1995) stressed that "defining spirituality in the workplace is like capturing an angel. It is ethereal and beautiful but perplexing" (p. 64). According to French existentialist Albert Camus: "without work, all life goes rotten but when work is soulless, life stifles and dies" (quoted in U.S. Department of Health, Education, and Welfare, 1973, p. xix). This quote explains the philosophy under the spirituality. They evaluate spirituality to create meaning in life, give meaning to actions in the workplace context. Amabile and Kramer (2012) found that employees who perceive their works as meaningful are more creative, productive, committed and collegial. Fry (2003) who has developed the model of spiritual leadership asserted that spirituality reveals and fulfill the deepest needs of leaders and followers to spiritually survive through creating a culture of hope, faith and altruistic love. Other scholars stated that having connection with higher source, putting the highest power before the business give helps leaders to face unexpected conditions with courage and confidence as well as keeping a strong connection with self, others and their environment (Howard, 2002; Pratt, 2000). One of the predictors of spirit at work is organizational culture in which the idea of organizational family is fostered and employees take care of each other as well as their customers (Freiberg \& Freiberg, 1996). According to symbolic interaction theory (Mead, 1934) human being interpret or define each other's actions or behaviors based on the meaning which they attach the actions. Thus, human interaction is mediated by symbols or interpretations. In this study, the action of spirit at work is predicted by organizational culture, and organization-based selfesteem which is seen a mediator variable between organizational culture and spirit 
at work. Organization-based self-esteem emphasizes one's sense of personal adequacy as a member in organization (Pierce, Gardner, Cummings, \& Dunham, 1989). Cognitive consistency theory suggests that employees who perceive themselves valuable and meaningful in organization will make an attempt on engaging behaviors (Korman, 1971).

Mechanistically designed social systems have negative effect on an impersonality of interpersonal relationships, job dissatisfaction and alienation (Chattopadhyay, 2003; Pierce et al., 1989). Therefore, organizational culture that masculine values are commonly shared might affect the existence of spirit at work lesser and organization based self-esteem might have a mediating role in this relationship. On the contrary, when employees feel that their organization is flexible, give importance to relationship and intimacy, they will tend to interpret this as "I am competent, valuable and contributing in this organization" which will resulted as increasing experience of positive affect, physical sensations and interpersonal connections. Put differently, the more individuals have interaction with the environment which encourages systems of beliefs about their self, the more those beliefs become part of the self (Korman, 1971) that might lead to one whose work makes contribution, have sense of connection with others and common purpose and awareness of connection larger than self.

\subsection{Spirituality and Its relation with similar concepts}

Spirituality is derived from Latin word spiritus, meaning breath of life and often defined as "a search for meaning, for unity, for connectedness, for transcendence, and for the highest of human potential" (Emmons, 1999, p. 5); "the basic feeling of being connected with one's complete self, others and the entire universe in a certain ends or purpose that go beyond self" (McKnight, 1984, p. 138); "individual lives meaningfully with ultimacy, his or her response to the deepest truths of the universe" (Bregman \& Thierman, 1995, p. 149); "the journey to find a sustainable, authentic, meaningful, holistic, and profound understanding of the existential self and its relationship/interconnectedness with the sacred and the transcendent"' (Karakas, 2010, p. 91).

In literature, there have been some terms overlap or related with spirituality. Some of them are altruism and self-actualization. Altruistic behavior has been defined as "behavior that benefits another organism, not closely related, while being apparently detrimental to the organism performing the behavior, benefit and detriment being defined in terms of contribution to inclusive fitness" (Trivers, 1971, p. 35). In spirituality literature, spirituality has often been linked to positive outcomes such as feelings of sympathy, empathy, compassion, involvement, 
tenderness, and gratitude (Valliant, 2008); more altruistic behavior (Saroglou, Pichon, Trompette, Verschueren, \& Dernelle, 2005); and experiencing more compassionate love for close others and strangers (Sprecher \& Fehr, 2005). These lines of evidence suggest that altruism is one of the expected types of behaviors where spirituality is experienced.

According to Maslow's theory of human motivation, when physiological, safety, love and esteem needs are satisfied, we may expect reaching of self-actualization (full humanness). Abraham Maslow defines self-actualization in his book of "Farther Reaches of Human Nature". "Self-actualization means experiencing fully, vividly, self-lessly, with full concentration and total absorption. It is an ongoing process that includes making a growth choice, listening to impulsive voices, being honest, taking responsibility, experiencing transient moments, and finding out who one is, what he is, what his mission'"(Maslow, 1971, p. 43-47). Maslow's (1971) point of view highlights that climax of self-actualization is a peak experience and it is a realization of ought and is. It is merging of subject and object, involving no loss of subjectivity, instead its infinite extension. Therefore, it can be concluded that one who has been experiencing a search for meaning, for unity, for connectedness, for transcendence, and for the highest of human potential has already been self-actualized. But, as the statement emphasized "if one need is satisfied, then another emerges", does not mean a need must be satisfied a hundred per cent to reach next need. According to Maslow (1943) as we go up the hierarchy of prepotency, the percentage of satisfaction level decreases. Therefore, we might say that people who have spiritual tendency are the ones mostly satisfy their needs in the hierarchy of needs and experience self-actualization.

\subsection{Spirit at work}

Spirit at work has been defined as a "distinct state that is characterized by cognitive, interpersonal, spiritual, and mystical dimensions. Spirit at work involves: engaging work characterized by a profound feeling of well-being, a belief that one is engaged in meaningful work that has a higher purpose, an awareness of alignment between one's values and beliefs and one's work, and a sense of being authentic; a spiritual connection characterized by a sense of connection to something larger than self; a sense of community characterized by a feeling of connectedness to others and common purpose; and a mystical or unitive experience characterized by a positive state of energy or vitality, a sense of perfection, transcendence, and experiences of joy and bliss" (Kinjerski \& Skrypnek, 2006, p. 16-17). 
The first dimension of spirit at work "engaging work" points out finding meaning in life by seeking meaningful work. Neck and Milliman $(1994$, p. 9) stated that "work is intended to be one of the most profound ways... of experiencing spirituality". According to Neck and Milliman (1994) employees might ask some question to find "meaning" in their work: "what is it that I have to offer? What is my purpose here at work or life? What do I want to leave behind here?" (p. 10). The answers of these questions determine the meaning in work. The second dimension "spiritual connection" emphasizes a connection to something greater than oneself. Ashforth and Pratt (2003) labelled it as a "transcendence of self". Something greater than oneself might be perceived as ambiguous. Ashforth and Pratt (2003, p. 93) suggested that the "something can be other people, causes, nature or a belief in a higher power". The third dimension "sense of community" states feeling of connection to others and common purpose. According to Krishnakumar and Neck (2002) sense of community at work is crucial for people to experience "that inexplicable feeling of connectedness with others and the universe" (p. 156) in order to be nourished by spirituality. The last dimension "mystical or unitive experience" points out sense of perfection, transcendence and experiences joy, bliss, awe-inspiring and mysterious, living in the moment are expanded in four conscious awareness: "(1) consciousness of self; (2) consciousness of other; (3) group consciousness; and (4) to organize in harmony with the unseen order of things" (Mirvis, 1997, p. 194-195). According to Hood (1975) mystical experience can be introvertive and extrovertive. Introvertive mystical experience includes consciousness of a timeless and spaceless ultimate void. Extrovertive mystical experience involves unity with all things. Similarly Stace (1960) observed that mystical experiences were generally characterized by a profound feeling of unity or interconnectedness, and resulted that the core experience of unity was "the essence of all mystical experience" (p. 132).

According to findings of Kinjerski and Skrypnek (2006) there are some factors that fosters employee's experience of spirit at work such as inspired leadership, strong organizational foundation, organizational integrity, positive workplace culture and space, sense of community among members, opportunities for personal fulfillment, continuous learning and development and appreciation and regard for employees and their contribution. In a similar vein, Krishnakumar and Neck (2002) highlighted that "spirituality is recognized as one of the considerable dimensions of the human personality. Therefore, if an organization encourages spirituality, then it is actually encouraging the people to bring their whole self to work' (p. 159). 


\subsection{Organizational Culture: Feminine vs. Masculine}

The concept of culture exists at different levels: national culture and organizational culture. Hofstede (1980) defined culture as "a mental programming that distinguishes a group of people from others" (p. 43). As for that, organizational culture is collective mental programming that separates members of an organization from any other members of any other organizations. With respect to masculine and feminine cultural assumptions Hofstede (1983) emphasized "Masculine and Feminine" national cultures as the division of roles between genders in the society. According to Acker (1990, p. 55) gender is configured "by means of the practices, images, ideologies and the transmission of power throughout the different sectors of the social life".

While masculine societies give importance of showing off, of making money, of achieving; feminine societies adapt feminine roles such as not showing off, giving importance to relationship with people rather than money, helping others, and preservation of environment. As an example, Hofstede (2001) claims that while masculine values are characterized by assertiveness and competitiveness, feminine values are characterized by modesty and cooperation. The other cultural characteristics such as high power distance, low uncertainty avoidance, individualism, and long term orientation are related with masculinity where as low power distance, high uncertainty avoidance, collectivism, and short term orientation are related with femininity.

Cliff, Langton and Aldrich (2005) defined the key dimensions of genderstereotypical organizational archetypes as follows: Feminine organizations are flat, downplay rules and standards, show responsiveness and attentiveness for the needs of others, they give importance to relational orientations. Masculine organizations are hierarchical, stick to the impersonal rules and standards, adopt an instrumental orientation, and see individuals as resources and mean in order to accomplish goals.

According to findings of Pool's study (2000), while a constructive organizational culture decreases role conflict and role ambiguity, the passive organizational culture increases role conflict and role ambiguity. In another study (Rashid, Sambasivan, \& Johari, 2003) it is found out that consensual organizational culture that fosters loyalty and team work has positive relationship with affective commitment, on the contrary, competitive organizational culture is positively related with continuance commitment. Additionally, consensual organizational culture has more positive contribution on financial performance (Return on Investment) of the organization than competitive organizational culture. In another 
study, Moghali and Maleki tabas (2009) found out that hierarchical organizational culture has negative contribution on organizational creativity whereas collaborative organizational culture has positive contribution on organizational creativity.

\subsection{Organization based Self-esteem}

Organization-based self-esteem (OBSE) is "the self-perceived value that individuals have of themselves as organization members acting within an organizational context (Pierce et al., 1989, p. 625). In order to fully understand OBSE, it is essential to state the definition of self-esteem. Self-esteem is the degree of a belief about individuals see themselves as a competent, need-satisfying and able (Korman, 1976). When an organization member evaluates himself as personally adequate, important, competent and capable within employing organization high OBSE occurs. This belief is resulted as "I count around here". In other words, OBSE reflects the self-perceived value of individuals in an organizational context.

There have some determinants of self-esteem that were highlighted by scholars (Brockner, 1988; Franks \& Marolla, 1976; Korman, 1970, 1971, 1976). These determinants are categorized as exposed implicit signals sent by the external environment; messages sent from other people in a social environment; the person's feeling of competence and efficacy acquired from his or her direct experiences (Pierce \& Gardner, 2004). According to Korman's (1976) selfconsistency motivational theory, employee self-esteem is shaped by work and organizational experiences and plays a crucial role in shaping employee motivation, work-related attitudes and behaviors. To increase OBSE perceived organizational support (Phillips, 2000), organization's socialization practices (Riordan, Weatherly, Vanderberg, \& Self, 2001) should take a part in organization. In a similar way, a research (Bowling, Eschleman, Wang, Kirkendall, \& Alarcon, 2010) found that employees who have autonomy, organizational support, social support from their supervisors and co-workers experience OBSE.

McAllister and Bigley (2002) found out that there is a positive relationship between organizational care and OBSE. In other words, employees whose values and needs are centered to fulfill employee motivation report higher levels of OBSE. In another study, Tang, Kim and O'Donald (2000) ascertained that organizational culture focused on family and open communication oriented, loyal and team focused were significant predictors of OBSE.

OBSE has various outcomes for the organization and the individual. Van Dyne, VandeWalle, Kostova and Cumming's (2000) study which points to positive relationship between trust and helping behavior, supports the mediating effect of 
OBSE. Employees who experience OBSE are found to be trusted with their organization and indented to helping behavior. Therefore, it can be asserted that experiences within an organizational environment will shape OBSE in turn will influence employee attitudes and behaviors. Employee, who experiences high OBSE will believe she/he counts, is taken seriously, is trusted, is helpful, is efficient, and makes a difference in organization. In a similar vein, Korman (1970) claimed that higher levels of self-esteem is likely to occur in the work context that is inherent trust in employees as competent, valuable and contributing individuals.

\subsection{The mediating effect of Organization-based Self-esteem on the relationship between Organizational Culture and Spirit at work}

In the context of this study, the relationship between feminine / masculine organizational culture, OBSE and spirit at work will be examined. As it was mentioned before, the relationship between organizational culture and spirit at work is examined and it is found that there is a positive relationship. More specifically, relationship or support oriented culture is positively correlated with the experience of spirituality at workplace. The important point here is how organizational culture is considered. When the relationship between feminine organizational culture and spirit at work is observed, the relationship oriented culture is taken into account and the positive relationship between two variables is supported (Dehler \& Welsh, 1994; Fry, 2003; Fry \& Cohen, 2009; Komala \& Ganesh, 2007). According to Fry (2003) organizational culture that fosters values of altruistic love, employees feel understood, and appreciated and have genuine care, concern would lead to spirituality at workplace. Similarly, organizational culture highlights "high values, honesty, trustworthy, positive attitude, passionate, optimistic, happy, compassionate, caring about people, and empathy" embraces spirit at work (Bolman \& Deal, 2001; Denton \& Mitroff, 1999; Kinjerski \& Skrypnek, 2004).

The implementations that comprise feminine organizational culture seem to increase spirit at work. Organizational context that give importance to relationships, helping others and preservation of environment are place that is more likely to experience spirit at work. Against that the relationship between masculine organizational culture and spirit at work is rarely studied in literature. Md. Zabid, Anantharaman and Raveendran (1997) found out that spirituality experiences are significantly different in terms of masculine organizational cultures. In other words, an organization in which masculine cultural values are dominant would be the context that spiritual values are less likely to be experienced. 
Although spirituality and masculine organizational culture is not handled often, experiencing spirit at work can probably and weakly explained by masculinity. While masculinity includes values of assertiveness, outperforming, competition, spirituality contains values of joy, meaning or real sense of trust. Hence, the occurrence of spirituality would be less with the existence of masculine values in the organization.

According to field theory (Lewin, 1952), the interaction between person and environment determines the behavior. In field theory, a "field" is defined as "the totality of coexistance facts which are conceived of as mutually interdependent" (Lewin, 1951, p. 240). Individuals are likely to behave differently with regard to where tensions between perceptions of the self and of the environment were scrutinized. In accordance with this, feminine organizational culture may encourage individuals to experience spirit at work. However, this relationship might be mediated by some variables. The present study targets the mediator role of organization based self-esteem. An organization in which relationship, flexibility, and intimacy is dominated will affect employees' self-perceived value as organization members and will contribute to experiencing of spirit at work.

The research about the relationship between organizational culture and OBSE is limited. According to findings of Pierce et al. (1989) there is a positive relationship between perceived managerial respect and OBSE, suggesting that being in an environment characterized by management's demonstration of positive regard for the individual will increase OBSE. Similarly, Pierce et al. (1989) highlighted that employees who have lower levels of OBSE exposed to mechanistically designed organization than those exposed to work in more organically designed organization. Considering that, it can be said that feminine organizational culture can increase experiencing of OBSE with respect to masculine organizational culture.

It can be said that an employee who experiences high OBSE feels secure in her/his capability to affect her/his working environment and feels like s/he is part of "a community" at work and because of positive perception about her/himself feels grateful to be involved in his work. Employees who perceive their inputs are appreciated experience value congruence with their organizations believe they can make real difference to the company and to others (Catlette \& Hadden, 1998). This might be considered one of the dimensions of spirit at work: sense of community. Other dimensions such as engaging work, spiritual connection and mystical experience might explained by Maslow's theory. According to hierarchy of needs, affiliation, esteem and self-actualization are considered higher-order needs. As workers started to become aware that their survival needs can be fulfilled even if 
they are fired or lost their jobs, many of them especially educated workers, started to begin to demand more than just money from their jobs (Drucker, 1993; Galbraith, 1967). They desired to fulfill their affiliation, esteem and even selfactualization growth needs in which personal and individual growth and bringing this growth into workplace are considered as spirituality in books (Bolman \& Deal, 1995; Jaworski, 1998). Employees who evaluate themselves as important members in the organization would likely to experience a high sense of service (Hawley, 1993) and eventually contribute their thoughts, potentials and energies for development of the organization (Block, 1993; Brown, 1992; Rosen, 1992). According to findings of Hsu and Kuo (2003) OBSE has positive association with ethical behavior and ethical intentions.

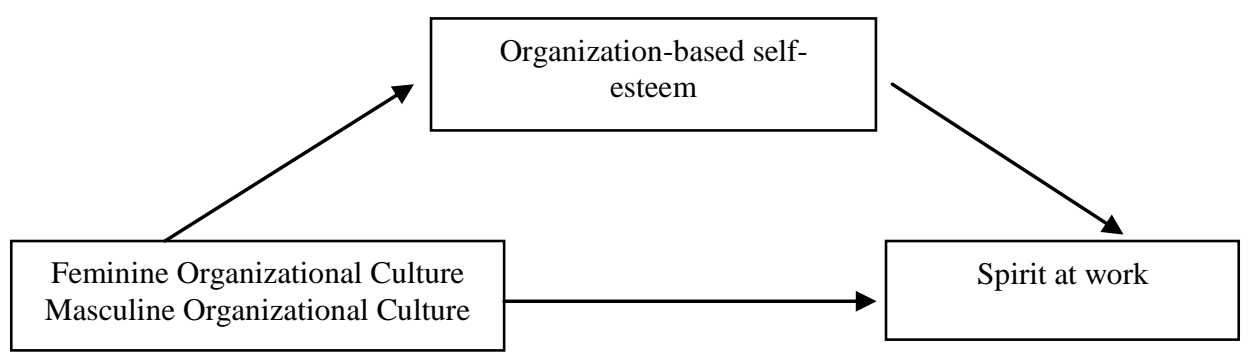

\section{Figure 1: Research model}

It is predicted that OBSE will partially mediate the relationship between feminine/masculine organizational culture and spirit at work. Since we are not able to draw cause-effect relations between variables in social sciences, instead of looking for a full mediator, we presume that there might be many other mediators between organizational culture and spirit at work and organization based selfesteem might be only one of them (Baron \& Kenny, 1986).

Accordingly it is predicted:

H1: Organization-based self-esteem partially mediates the relationship between feminine organizational culture and spirit at work.

$\mathrm{H} 2$ : Organization-based self-esteem partially mediates the relationship between masculine organizational culture and spirit at work. 


\section{METHOD}

In order to analyze the proposed model empirically, the data was collected from academicians working at public and private universities in Turkey. Reaching a considerable number of respondents was achieved by web-based questionnaire as a survey form. The first page of the survey form provided purpose of the study and assurance of anonymity and confidentiality.

\subsection{Participants/subjects}

In total, 417 completed surveys were returned out of approximately 3500 . This shows a response rate of 11.9 per cent. The total sample contained 35\% ( $\mathrm{n}=148)$ female and $65 \%(\mathrm{n}=269)$ male participants. The average age of respondents was 40. With respect to marital status, $73 \%(n=304)$ of the participants were married, and $27 \%(\mathrm{n}=113)$ were single. With respect to professional level $26 \%(\mathrm{n}=106)$ of the participants were research assistant, $15 \%(\mathrm{n}=63)$ were teaching assistant, $30 \%$ $(\mathrm{n}=120)$ were assistant professor, $14 \%(\mathrm{n}=58)$ were associate professor, and $15 \%$ $(n=63)$ were professor. The participants had an average of 16 years in their current job, 8 years in their university.

\subsection{Instruments}

\subsubsection{Spirit at work scale}

To measure spirit at work Kinjerski and Skrypnek (2006) 18 item scale was used. This instrument includes four dimensions: engaging work (e.g., "I experience a match between the requirements of my work and my values, beliefs and behaviors"), sense of community (e.g., "I feel like I am part of "a community" at work"), spiritual connection (e.g., "My spiritual beliefs play an important role in everyday decisions that I make at work"), and mystical experience (e.g., "At times, I experience an energy or vitality at work that is difficult to describe"). Participants respond by indicating their agreement to each of 18 items using six point scale ranging from 1 (definitely disagree) to 6 (definitely agree).

\subsubsection{Organization preference scale}

Feminine/Masculine Organizational culture was measured by 10-item OrganizationalPreference (OP) scale that has been developed by Catanzaro, Moore and Marshall (2010). OP has two sub-dimensions: feminine organizational culture (e.g., "I would prefer to work in an organization that values my being supportive and helpful to others in my department") and masculine organizational culture (e.g., "I would prefer to work in an organization that values being winner and outperforming my peers"). The original version of scale asks the preferences for 
the values that represent a competitive (masculine) or supportive (feminine) organizational culture. In this study, items of the scale were revised as omitting "preference" word in sentences. For instance, the item "I would prefer to work in an organization that would allow me to balance my work and family life, even if it meant earning lower salary" was changed into a "I work in an organization that allows me to balance my work and family life, even if it meant earning lower salary". Participants respond by indicating their agreement to each of 10 items using six point scale ranging from 1 (definitely disagree) to 6 (definitely agree).

The original items of both spirit at work and OP scales were translated into Turkish by the authors. Re-examination and appropriate corrections have been carried out by a group of specialists who are proficient in both languages in order to check the meaning unity with the English version. Following this, both scales were piloted on a sample of 33 respondents and high reliability levels were obtained (alpha $=.93$ for spirit at work, and alpha $=.89$ for $\mathrm{OP}$ ).

\subsubsection{Organization based self-esteem scale}

Pierce et al. (1989) 10 item organizational based self-esteem scale translated into Turkish and found highly reliable (Cronbach's Alpha $=.93$ ) by Erden (2011) was used. Participants respond by indicating their agreement to each of 10 items using six point scale ranging from 1 (definitely disagree) to 6 (definitely agree).

\section{FINDINGS}

\subsection{Factor structure of the scales}

Exploratory factor analyses (EFA) were conducted to test the each scale's underlying patterns. Kaiser-Meyer-Olkin measure of sampling adequacy and Bartlett test of sphericity tests showed the appropriateness of the data for performing factor analyses. Principle component method and varimax rotation technique are applied to the data set. Cronbach's Alpha reliability analyses were applied to determine internal consistency of the measurement tools.

The exploratory factor analysis for spirit at work revealed four-factor structure $(\mathrm{KMO}=.91$ and Bartlett's Test of Sphericity Chi Square: 6020.788 df: 153; $p<$ .001 ) explaining $74.7 \%$ of the total variance. The items are distributed in a parallel way with the original scale, the factor names are preserved the same. Only item 7 which represents "engaging work" has come under "sense of community" dimension with relatively low factor loading. Items of each factor, factor loadings and factor variances are shown in Table 1. The Cronbach's alpha reliabilities were $.92, .90, .90$ and .80 respectively (See Table 3 ). 
Table 1: Factor analysis results of spirit at work

\begin{tabular}{|c|c|c|}
\hline Factor Name & Items & $\begin{array}{c}\text { Factor } \\
\text { Loadings }\end{array}$ \\
\hline \multirow{7}{*}{$\begin{array}{l}\text { Engaging } \\
\text { work }\end{array}$} & 2) I am able to find meaning or purpose at work. & .829 \\
\hline & 3)I am passionate about my work. & .792 \\
\hline & $\begin{array}{l}\text { 1)I experience a match between the requirements of my work } \\
\text { and my values, beliefs and behaviors. }\end{array}$ & .789 \\
\hline & 4)I am fulfilling my calling through my work. & .770 \\
\hline & $\begin{array}{l}\text { 5)I have a sense of personal mission in life, which my work } \\
\text { helps me to fulfill. }\end{array}$ & .740 \\
\hline & 6)I feel grateful to be involved in work like mine. & .674 \\
\hline & Factor Variance \% & 24.47 \\
\hline \multirow{6}{*}{$\begin{array}{l}\text { Mystical } \\
\text { Experience }\end{array}$} & 10) At moments, I experience complete joy and ecstasy at & .832 \\
\hline & 9)I have moments at work in which I have no sense of time & .821 \\
\hline & $\begin{array}{l}\text { 12) At times, I experience an energy or vitality at work that is } \\
\text { difficult to describe. }\end{array}$ & .752 \\
\hline & 11) I experience moments at work where everything is & .731 \\
\hline & 8)At times, I experience a "high" at work. & .716 \\
\hline & Factor Variance \% & 20.86 \\
\hline \multirow{4}{*}{$\begin{array}{l}\text { Spiritual } \\
\text { Connection }\end{array}$} & $\begin{array}{l}\text { 15) I experience a connection with a greater source that has a } \\
\text { positive effect on my work. }\end{array}$ & .894 \\
\hline & 14) I receive inspiration or guidance from a Higher Power & .862 \\
\hline & $\begin{array}{l}\text { 13) My spiritual beliefs play an important role in everyday } \\
\text { decisions that I make at work. }\end{array}$ & .798 \\
\hline & Factor Variance \% & 15.35 \\
\hline \multirow{6}{*}{$\begin{array}{l}\text { Sense of } \\
\text { community }\end{array}$} & $\begin{array}{l}\text { 17) I experience a real sense of trust and personal connection } \\
\text { with my coworkers. }\end{array}$ & .932 \\
\hline & $\begin{array}{l}\text { 18) I share a strong sense of purpose and meaning with my } \\
\text { coworkers about our work. }\end{array}$ & .907 \\
\hline & 16) I feel like I am part of “a community” at work. & .555 \\
\hline & 7) At the moment, I am right where I want to be at work. & .406 \\
\hline & Factor Variance \% & 14.01 \\
\hline & TOTAL VARIANCE EXPLAINED \% & 74.7 \\
\hline
\end{tabular}

As expected, the obtained factor structure for Feminine / Masculine Organizational Culture was revealed as two factor solutions $(\mathrm{KMO}=.84$ and Bartlett's Test of Sphericity Chi Square: 1816.747 df: 36; $p<.001$ ) explaining $66.95 \%$ of total 
variance. One item (e.g., I work in an organization where rewards are distributed equally in my workgroup) which belongs to feminine organizational culture was removed from the analyses due to it comes under two factors with high and close loadings. Items of each factor, factor loadings and factor variances are shown in Table 2. The Cronbach's alpha reliabilities were .86 and .81 respectively (See Table 3). For OBSE scale, factor analysis was not performed, due to the fact that it is accepted as a unidimensional variable (Pierce et al., 1989).

Table 2: Factor analysis results of organizational culture

\begin{tabular}{|c|c|c|}
\hline Factor Name & Items & $\begin{array}{c}\text { Factor } \\
\text { Loadings }\end{array}$ \\
\hline \multirow{5}{*}{$\begin{array}{l}\text { Feminine } \\
\text { Organizational } \\
\text { Culture }\end{array}$} & $\begin{array}{l}\text { 4) I work in an organization that values being } \\
\text { supportive and helpful to others in my department. } \\
\text { 2) I work in an organization that would allow me to } \\
\text { balance my work and family life, even if it meant } \\
\text { earning a lower salary. }\end{array}$ & .823 \\
\hline & $\begin{array}{l}\text { 1)I work in an organization that values collaboration } \\
\text { with other employees in my department. }\end{array}$ & .790 \\
\hline & $\begin{array}{l}\text { 3) I work in an organization that values my working } \\
\text { independently from other employees. }\end{array}$ & .752 \\
\hline & $\begin{array}{l}\text { 10) I work in an organization that realizes I have a life } \\
\text { outside of my career, even if the salary is less than I } \\
\text { could earn in a more demanding job. }\end{array}$ & .741 \\
\hline & Factor Variance \% & 37.62 \\
\hline \multirow{6}{*}{$\begin{array}{l}\text { Masculine } \\
\text { Organizational } \\
\text { Culture }\end{array}$} & $\begin{array}{l}\text { 5) I work in an organization that provides me the } \\
\text { opportunity to have high salary earnings, even if it } \\
\text { meant sacrifices regarding my personal and family life. }\end{array}$ & .862 \\
\hline & $\begin{array}{l}\text { 7) I work in an organization that views high salary and } \\
\text { career advancement as the main focus of my life even } \\
\text { if the job was very demanding and required } 60 \mathrm{~h} \text { work } \\
\text { weeks. }\end{array}$ & .826 \\
\hline & $\begin{array}{l}\text { 6) I work in an organization that allows me to be } \\
\text { competitive with my colleagues for rewards. }\end{array}$ & .774 \\
\hline & $\begin{array}{l}\text { 9) I work in an organization that values being a winner } \\
\text { and outperforming my peers. }\end{array}$ & .628 \\
\hline & Factor Variance $\%$ & 29.33 \\
\hline & TOTAL VARIANCE EXPLAINED \% & 66.95 \\
\hline
\end{tabular}




\subsection{Correlation among variables}

Table 3 provides means, standard deviations, reliabilities, and zero-order correlations for the variables in this study.

As seen in Table 3, participants scored themselves highest on engaging work $(\mathrm{m}=$ $4.75, \mathrm{sd}=1.06)$ followed by OBSE $(\mathrm{m}=4.49, \mathrm{sd}=.95)$ and spirit at work $(\mathrm{m}=$ $4.16, \mathrm{sd}=.95)$. The mean score of feminine organizational culture perception $(\mathrm{m}=$ $3.50, \mathrm{sd}=1.12)$ was higher than that of masculine organizational culture $(\mathrm{m}=2.44$, $\mathrm{sd}=1.03)$. After engaging work, participants' spiritual experiences are highest on mystical experience $(\mathrm{m}=3.96$, $\mathrm{sd}=1.15)$ followed by spiritual connection $(\mathrm{m}=$ $3.88, \mathrm{sd}=1.49)$ and sense of community $(\mathrm{m}=3.72, \mathrm{sd}=1.12)$.

Table 3: Means, standard deviations, reliabilities, and correlations of scales

\begin{tabular}{lcccccccccc}
\hline Variables & Mean & SD & $\mathbf{1}$ & $\mathbf{2}$ & $\mathbf{3}$ & $\mathbf{4}$ & $\mathbf{5}$ & $\mathbf{6}$ & $\mathbf{7}$ & $\mathbf{8}$ \\
\hline $\begin{array}{l}\text { 1.Spirit at } \\
\text { work }\end{array}$ & 4.16 & 0.95 & $0.92 \mathrm{a}$ & - & - & - & - & - & - & - \\
$\begin{array}{l}\text { 2.Feminine } \\
\text { Org.Culture }\end{array}$ & 3.50 & 1.12 & $.53^{* *}$ & $0.86 \mathrm{a}$ & - & - & - & - & - & - \\
$\begin{array}{l}\text { 3.Masculine } \\
\text { Org.Culture }\end{array}$ & 2.44 & 1.03 & $.40^{* *}$ & $.44^{* *}$ & $0.82 \mathrm{a}$ & - & - & - & - & - \\
4.OBSE & 4.49 & 0.95 & $.47^{* *}$ & $.45^{* *}$ & $.28^{* *}$ & $0.92 \mathrm{a}$ & - & - & - & - \\
5.Eng.Work & 4.75 & 1.06 & $.87^{* *}$ & $.45^{* *}$ & $.32^{* *}$ & $.47^{* *}$ & $0.92 \mathrm{a}$ & - & - & - \\
6.Mys.Exp & 3.96 & 1.15 & $.83^{* *}$ & $.33^{* *}$ & $.33^{* *}$ & $.35^{* *}$ & $.66^{* *}$ & $0.90 \mathrm{a}$ & - & - \\
7.Sp.Con. & 3.88 & 1.49 & $.74^{* *}$ & $.37^{* *}$ & $.31^{* *}$ & $.25^{* *}$ & $.50^{* *}$ & $.48^{* *}$ & $0.90 \mathrm{a}$ & - \\
8.S.of Com. & 3.72 & 1.12 & $.75^{* *}$ & $60^{* *}$ & $.31^{* *}$ & $.44^{* *}$ & $.55^{* *}$ & $.47 * *$ & $.49 * *$ & $0.80 \mathrm{a}$
\end{tabular}

Notes: a: Cronbach's alpha; OBSE: Organization based self-esteem; Eng.Work: engaging work; Mys.Exp: Mystical Experience; Sp.Con.: Spiritual Connection; S.of Com.:Sense of Community

$* * p<.01$ 
As it can be seen in Table 3, spirit at work has stronger positive relationship with feminine organizational culture $(r=.53, p<.01)$ than with masculine organizational culture $(r=.40, p<.01)$. OBSE has significant and positive relationship with spirit at work $(r=.47, p<.01)$, feminine organizational culture $(r$ $=.45, p<.01)$, and masculine organizational culture $(r=.28, p<.01)$. Yet, its relationship with spirit at work and feminine organizational culture is stronger than with masculine organizational culture. Pearson correlation analysis showed positive and significant relationships among sub-dimensions of spirit at work supporting the findings by Kinjerski and Skrypnek (2006).

Feminine organizational culture has positive relationship with engaging work ( $r=$ $.45, p<.01)$, mystical experience $(r=.33, p<.01)$, spiritual connection $(r=.37, p<$ $.01)$ and sense of community $(r=.60, p<.01)$. Masculine organizational culture has also positive but relatively weaker correlation with engaging work $\left(r=.32, p^{<}\right.$ $.01)$, mystical experience $(r=.33, p<.01)$, spiritual connection $(r=.31, p<.01)$ and sense of community $(r=.31, p<.01)$. When OBSE increases engaging work $(r$ $=.47, p<.01)$, sense of community $(r=.44, p<.01)$, mystical experience $(r=.35$, $p<.01)$ and spiritual connection $(r=.25, p<.01)$ increases.

\subsection{Hypothesis Testing}

According to Baron and Kenny (1986) a variable can be a mediator if it meets the following conditions: (a) Variations in levels of the independent variable significantly account for variations in the presumed mediator; (b) Variations in the mediator significantly account for variations in the dependent variable; (c) A previously significant relationship between independent and dependent variable must be reduced or disappears when the mediator is inserted into analyze.

The effects of feminine/masculine organizational culture on OBSE and spirit at work were analyzed in two multiple regression models that involved all two measures of organizational culture as independent variables (See Table 4). In the first model (with spirit at work as dependent variable), both of organizational culture dimensions were found to be significantly related to spirit at work $\left(F_{\mathrm{SAW}}=\right.$ 97.265, $p<.001)$. Among two organizational culture dimensions, feminine organizational culture (FOC) has the strongest affect on SAW with $\beta_{\mathrm{FOC}}=.447, p<$ .001 . Moreover, masculine organizational culture (MOC) has significantly and positively affected SAW with $\beta_{\mathrm{MOC}}=.201, p<.001$ (Table 4).

The second model which tested the contributions of feminine and masculine organizational culture dimensions on OBSE was found statistically significant $\left(F_{\mathrm{OBSE}}=55.419, p<.001\right)$. In this model, feminine organizational culture (FOC) had the strongest affect on OBSE with $\beta_{\mathrm{FOC}}=.405, p<.001$. Moreover, masculine 
organizational culture (MOC) was found to be positively affected to OBSE with $\beta_{\text {MOC }}=.103, p<.05$ (Table 4).

Table 4: The effects of organizational culture dimensions on organization based self-esteem and Spirit at work

\begin{tabular}{|c|c|c|c|c|}
\hline \multirow[t]{2}{*}{ Independents } & \multicolumn{2}{|c|}{ OBSE } & \multicolumn{2}{|c|}{ Spirit at work } \\
\hline & $\boldsymbol{\beta}$ & $t$ & $\beta$ & $t$ \\
\hline $\begin{array}{l}\text { Feminine } \\
\text { Org.Cul. }\end{array}$ & $.405^{* * *}$ & 8.318 & $.447 * * *$ & 9.890 \\
\hline $\begin{array}{l}\text { Masculine Org. } \\
\text { Cul. }\end{array}$ & $.103^{*}$ & 2.115 & $.201 * * *$ & 4.453 \\
\hline $\boldsymbol{F}$ & \multicolumn{2}{|c|}{$55.419 * * *$} & \multicolumn{2}{|c|}{$97.265 * * *$} \\
\hline & \multicolumn{2}{|c|}{.212} & \multicolumn{2}{|c|}{.320} \\
\hline Adjusted $R^{2}$ & \multicolumn{2}{|c|}{.208} & \multicolumn{2}{|c|}{.317} \\
\hline
\end{tabular}

The last model which was applied to determine the mediator effect of OBSE by inserting it as an independent variable together with feminine and masculine organizational culture was found to be statistically significant $\left(F_{\mathrm{SAW}}=84.701, p<\right.$ .001). In the model with spirit at work as dependent variable, contribution of feminine organizational culture is reduced $\left(\beta_{\mathrm{FOC}}=.334, p<.001\right)$, but remained significant (See Table 5). Besides, OBSE was found to be significantly contributed to spirit at work $\left(\beta_{\mathrm{OBSE}}=.279, p<.001\right)$ but its contribution is lower than the contribution of feminine organizational culture. Thus, the first hypothesis that OBSE partially mediates the relationship between feminine organizational culture and spirit at work was not supported. The contribution of masculine organizational culture on spirit at work is also reduced $\left(\beta_{\mathrm{MOC}}=.173, p<.001\right)$, but was still significant. Hence, the second hypothesis that OBSE partially mediates the relationship between masculine organizational culture and spirit at work was not supported. These findings indicate that feminine, masculine organizational culture and OBSE statistically explain spirit at work independently of each other. 
Table 5: Test of mediating effect of Organization based self-esteem

\begin{tabular}{lccc}
\hline Independents & $\boldsymbol{\beta}$ & Spirit at work & $\boldsymbol{t}$ \\
\hline Feminine Org.Cul. & $.334^{* * *}$ & & 7.164 \\
Masculine Org. Cul. & $.173^{* * *}$ & & 3.976 \\
OBSE & $.279^{* * *}$ & & 6.389 \\
$\boldsymbol{F}$ & & $84.701^{* * *}$ & \\
$\boldsymbol{R}^{2}$ & & .381 & \\
Adjusted $\boldsymbol{R}^{2}$ & & .377 & \\
\hline$* * \mathrm{p}<.001$ & &
\end{tabular}

\subsection{The contributions of feminine and masculine organizational culture on sub-dimensions of spirit at work}

In order to test the contributions of feminine and masculine organizational culture on four sub-dimensions of spirit at work four separate multiple regression analyses were applied. Each of these regression models was found statistically significant (See Table 6). Beta coefficients revealed that the contributions of both feminine and masculine organizational culture are in positive direction; however the amounts of contributions on each sub-dimension of spirit at work differ. Regarding the sub-dimension engaging work, compared to masculine organizational culture $\left(\beta_{\mathrm{MOC}}=.154, p<.01\right)$, feminine organizational culture $\left(\beta_{\mathrm{FOC}}\right.$ $=.382, p<.001)$ contributes more strongly. With regard to spiritual connection, similarly, the contribution of feminine organizational culture $\left(\beta_{\mathrm{FOC}}=.288, p<.001\right)$ is stronger than the contribution of masculine organizational culture $\left(\beta_{\mathrm{MOC}}=.185\right.$, $p<.001)$. Relating to mystical experience, feminine organizational culture $\left(\beta_{\mathrm{FOC}}=\right.$ $.227, p<.001)$ and masculine organizational culture $\left(\beta_{\mathrm{MOC}}=.229, p<.001\right)$ contribute in equal amounts. With regard to sense of community, only feminine organizational culture has significant contribution $\left(\beta_{\mathrm{FOC}}=.573, p<.001\right)$. 
Table 6: The contribution of feminine and masculine organizational culture on subdimensions of spirit at work

\begin{tabular}{|c|c|c|c|c|c|c|c|c|}
\hline \multirow[t]{2}{*}{ Independents } & \multicolumn{2}{|c|}{ Engaging Work } & \multicolumn{2}{|c|}{$\begin{array}{c}\text { Mystical } \\
\text { Experience }\end{array}$} & \multicolumn{2}{|c|}{$\begin{array}{l}\text { Sense of } \\
\text { Community }\end{array}$} & \multicolumn{2}{|c|}{$\begin{array}{l}\text { Spiritual } \\
\text { Connection }\end{array}$} \\
\hline & $\beta$ & $t$ & $\beta$ & $t$ & $\beta$ & $t$ & $\beta$ & $t$ \\
\hline $\begin{array}{l}\text { Feminine } \\
\text { Org.Cul. }\end{array}$ & $.382 * * *$ & 7.890 & $.227 * * *$ & 4.494 & $.573 * * *$ & 13.113 & $.288 * * *$ & 5.735 \\
\hline $\begin{array}{l}\text { Masculine } \\
\text { Org. Cul. }\end{array}$ & $.154 * *$ & 3.172 & $.229 * * *$ & 4.535 & .065 & 1.494 & $.185^{* * *}$ & 3.683 \\
\hline$F$ & \multicolumn{2}{|c|}{$58.994 * * *$} & \multicolumn{2}{|c|}{$36.737 * * *$} & \multicolumn{2}{|c|}{$118.968 * * *$} & \multicolumn{2}{|c|}{$40.691 * * *$} \\
\hline $\boldsymbol{R}^{2}$ & \multicolumn{2}{|c|}{.222} & \multicolumn{2}{|c|}{.151} & \multicolumn{2}{|c|}{.366} & \multicolumn{2}{|c|}{.164} \\
\hline Adjusted $R^{2}$ & \multicolumn{2}{|c|}{.218} & \multicolumn{2}{|c|}{.147} & \multicolumn{2}{|c|}{.362} & \multicolumn{2}{|c|}{.160} \\
\hline
\end{tabular}

\section{Discussion and Conclusion}

Although spirit at work research has increased over the past decade, few studies have examined antecedents of spirituality. The purpose of this study was to investigate the relationships of organizational culture and OBSE with spirit at work. Our results extend the spirit at work literature in a number of important ways.

The results of factor analysis supported four component structure of spirit at work namely, engaging work, mystical experience, spiritual connection and sense of community. The distributions of the items into these four dimensions are consistent with the distribution of the original scale except one item, "at the moment, I am right where I want to be at work" which was expected to show up in the dimension of engaging work, but instead it was loaded under the dimension of sense of community. According to findings of Kinjerski and Skrypnek (2006) this item has relatively low factor loading as well. We can say that "engaging work" dimension focuses on the meaning, purpose and sense of personal mission in life and work, therefore "At the moment, I am right where I want to be at work" might not be perceived as creating meaning or fulfilling calling through work instead it might be perceived as interpersonal relations which can contribute to the working position of individuals. So, this item does seem not adequately represent the concept of engaging work, thus should be revised accordingly. Moreover, we can accept the spirit at work scale successful when we take into consideration the variance explanation power of the scale (74.7\%) and reliability level of each dimension (.92, $.90, .90, .80)$. 
Organizational culture was formed two dimensional structures as expected. However, one item "I work in an organization that values my working independently from other employees" that reflects the masculine organizational culture value was loaded under feminine organizational culture value. The reason behind of this loading might be explained by the perception of academicians. Because academic life necessitates working, for the most part, independently from other people, it might not be perceived as a masculine or assertive value as original scale's findings. Additionally, we can accept feminine/masculine organizational culture scale successful when we take into consideration the variance explanation power of the scale $(66.9 \%)$ and reliability level of each dimension $(.86, .81)$.

The research model was based on the partial mediating effects of organization based self-esteem on the relationship between organizational culture (i.e., feminine and masculine) and spirit at work. According to findings, organization based selfesteem does not have mediating role; yet it has an antecedent role on experiencing spirit at work. OBSE has been defined as a sense of worthiness experienced in the organization. Because organization based self-esteem is organization-related phenomena it should be related with the task or organizational construct (Pierce et al., 1989).

As Maslow (1971) highlighted esteem is a higher-need and involves dignity, autonomy, self-respect, respect from the other; sense of worth, getting praise and rewards. By definition, self-actualizing people have feeling of rootedness, they are satisfied with their needs of love, they have feeling of respect, love and worth. At this level, work is transcended which spirituality points out. Therefore, one who is apprised, loved, valued by her/his organization will fulfill higher-need (self-esteem in an organizational level) and she/he is going to be her/his own kind of person, real person and self-actualized person. As a result, it can be concluded that selfesteem that is provided by organization (OBSE) may promote positive relationship with other people, sense of meaning, mystical experience and spiritual connection at work. In other words, academicians who believe they are efficient, helpful, trusted in organization have tendency to experience spirit at work.

Results of multiple regression analysis confirmed that, both feminine and masculine organizational cultures are antecedents of spirit at work. As expected, feminine organizational culture has more contribution on experiencing spirit at work than masculine organizational culture. In other words, academicians who work in an organization that values being supportive and helpful to others tend to experience more physical, affective, cognitive, interpersonal, spiritual and mystical sensations at work than academicians who work in an organization that values being a winner and outperforming peers. These findings are not surprising because 
organizations that realize work-life balance of individuals, give values to collaboration with other employees might create an environment to experience spirit at work. However, when we examine the associations of sub-dimensions of spirit at work with feminine and masculine organizational culture, the relatively highest relation is only seen between sense of community and feminine organizational culture. The reason behind of this might be explained by the reflections of sense of community dimension. Sense of community focuses on the sense of connection to others like feminine organizational culture. Therefore, academicians who work in an organization that values relationship and intimacy are tend to feel like they are part of community at work or experience a real sense of trust and personal connection with coworkers. Moreover, Feminine organizational culture has significantly more contribution power on OBSE than masculine organizational culture. These findings are corroborative for findings of Bowling et al. (2010).

Masculine organizational culture has the highest explanatory power on mystical experience and the lowest on sense of community. These findings are interesting because both of the organizational culture types have almost same contributions on mystical experience. We can say that there is no contribution difference for mystical experience with respect to organizational culture types. Because mystical experience reflects sense of perfection, transcendence, living in the moment, experiencing awe-inspiring, mysterious and sacred (Kinjerski \& Skrypnek, 2004), it might not be explained only by environmental conditions. The fact that, it is harmony of unseen (Mirvis, 1997), and might affect the environment not be affected by it.

\subsection{Managerial Implications}

It can be concluded that although spirit at work is something unseen and metaphysical phenomena it plays a part in organizations. Supportive and relationship-oriented organizational culture leads to experiencing of spirit at work. Academicians who work in supportive organizational context are more engaged in meaningful work, experience sense of community, feel connection with larger than themselves and mystically aware of living in the moment that are awe-inspiring or sacred. Additionally, academicians who believe they are trusted, helpful, efficient, important, and taken seriously in their universities tend to experience spirit at work.

The results of this study suggest that universities should seek to convert their organizational culture into feminine culture and by implementing work processes and human resource policies the positive signals can be sent to the academicians that they are valuable, trusted or important in their universities to increase the 
experiencing of meaningful work, value and work congruency, complete joy and ecstasy at work, connection with a greater source that has a positive effect on work and real sense of trust and personal connection with co-workers.

\subsection{Limitations}

Generalizability of the findings to the academician population, and to other sectors, in Turkey is the main limitation of the study due to the data was collected through convenience sampling method. Hence, the generalizability of the findings necessitates the repetition of the study on other samples. The mediating effects of organization based self-esteem on the relationship between organizational culture and spirit at work might also be investigated for the future research.

\section{References and notes:}

1. Acker, J. (1990). Hierarchies, Jobs and bodies: A gendered Theory of Organizations. Gender and Society, 4(2), 139-158.

2. Amabile, T., \& Kramer, S. (2012). McKinsey Quarterly, January 2012, from http://www.mckinseyquarterly.com/How_leaders_kill_meaning_at_work_2910.

3. Ashforth, B., \& Pratt, M. (2003). Institutionalized spirituality: An oxymoron? In R. Giacalone, \& C. L. Jurkiewicz (Eds.).Handbook of workplace spirituality and organizational performance (pp. 93-107). New York: Sharpe.

4. Baron, R. M., \& Kenny, D. A. (1986). The Moderator-Mediator Variable Distinction in Social Psychological Research: Conceptual, Strategic, and Statistical Considerations. Journal of Personality and Social Psychology, 51, 1173-1182.

5. Benefiel, M. (2003). Irreconcilable foes? The discourse of spirituality and the discourse of organizational science. Organization, 10 (2), 383-91.

6. Block, P. (1993). Stewardship: Choosing Service Over Self Interest. BerrettKoehler, San Francisco.

7. Bolman, L., \& Deal, T. (2001). Leading with Soul. San Francisco, CA: Jossey-Bass.

8. Bolman, L. \& Deal, T. (1995). Leading With Soul. Jossey-Bass Publishers; San Francisco, Ca.

9. Bowling, N. A., Eschleman, K. J., Wang, Q., Kirkendall, C., \& Alarcon, G. (2010). A meta-analysis of the predictors and consequences of organization-based selfesteem. Journal of Occupational and Organizational Psychology, 83, 601-626.

10. Bregman, L., \& Thierman, S. (1995). First person mortal: Personal narratives of illness, dying, and grief. New York: Paragon.

11. Brockner, J. (1988). Self-esteem at work: Theory, research, and practice. Lexington, MA: Lexington Books.

12. Brown, J. (1992). Corporation as community: a case for a new era. In Renesch, J. (Eds.), New Traditions in Business: Spirit and Leadership in the 21st Century. Berrett-Koehler, San Francisco, CA, pp. 123-39. 
13. Catanzaro, D., Moore, H., \& Marshall, T.R. (2010). The impact of organizational culture on attraction and recruitment of job applicants. Journal of Business and Psychology, 25(4), 649-662.

14. Catlette, B., \& Hadden, R. (1998). Contented cows give better milk. Germantown, TN: Saltillo Press.

15. Chattopadhyay, P. (2003). Can dissimilarity lead to positive outcomes? The influence of open versus closed minds. Journal of Organizational Behavior, 24, 205-312.

16. Cliff, J., Langton, N., \& Aldrich, H. (2005) Walking the talk? Gendered rhetoric vs. action in small firms. Organization Studies, 26 (1): 63-91.

17. Dehler, G. E., \& Welsh, M. A. (1994). Spirituality and organizational transformation: Implications for the new management paradigm. Journal of Managerial Psychology,9, 17-27.

18. Denton, E. A., \& Mitroff, I. I. (1999). A spiritual audit of corporate America: A hard look at spirituality, religion, and values in the workplace. San Francisco, CA: Jossey-Bass; $12-45$.

19. Emmons, R. A. (1999). The psychology of ultimate concerns: Motivation and spirituality in personality. New York: Guilford.

20. Drucker, P. F. (1993). Postcapitalist Society. New York: Herper Collins Publishers.

21. Erden, N. S. (2011). Mediating Effects of Organization Based Self Esteem on the Relationship between Organizational Justice and Organizational Commitment. Unpublished Dissertation, Marmara University, Turkey.

22. Franks, D. D., \& Marolla, J. (1976). Efficacious action and social approval as interacting dimensions of self-esteem: A tentative formulation through construct validation. Sociometry, 39, 4324-4341.

23. Freiberg, K., \& Freiberg, J. (1996). Nuts! Southwest Airlines' Crazy Recipe for Business and Personal Success. Bard Books, Austin, TX.

24. Fry, L. W. (2003). Toward a Theory of Spiritual Leadership. The Leadership Quarterly, 14(6):

25. 693-727.

26. Fry, L. W., \& Cohen, M. P. (2009). Spiritual leadership as a paradigm for organizational transformation and recovery from extended work cultures. Journal of Business Ethics, 84, 265-278.

27. Galbraith, J. K. (1967) The New Industrial State. Boston, Houghton Mifflin.

28. Hawley, J. (1993), Reawakening the Spirit in Work: The Power of Dharmic Management. Berrett-Koehler Publishers, San Francisco, CA.

29. Hofstede, G. (1980). Culture's Consequences: International Differences in WorkRelated Values. Beverly Hills/London: Sage Publications.

30. Hofstede, G. (1983). The Cultural Relativity of Organizational Practices and Theories, Journal of International Business Studies, 14(2), 75-89.

31. Hofstede, G. (2001). Culture's Consequences: Comparing Values, Behaviors, Institutions and Organizations Across Nations (2nd ed.). London: Sage.

32. Hood, R. W. (1975). The construction and preliminary validation of a measure of reported mystical 
33. experience. Journal for the Scientific Study of Religion, 14 (1), 29-41.

34. Howard, S. (2002). A spiritual perspective on learning in the workplace. Journal of Managerial

35. Psychology, 17 (3), 230-242.

36. Hsu, M. H., \& Kuo, F. Y. (2003). The effect of organization-based self-esteem on deindividuation in protecting personal information privacy. Journal of Business Ethics, 42, 305-320.

37. Jaworski, J. (1998). Synchronicity: The Inner Path of Leadership. Berrett-Koehler, San Francisco, CA.

38. Karakas, F., (2010). Spirituality and performance in organizations: a literature review. Journal of Business Ethics, 94 (1), 89-106.

39. Kinjerski, V. M., \& Skrypnek, B. J. (2004). Defining spirit at work: finding common ground. Journal of Organizational Change Management, 17, 26-42.

40. Kinjerski, V. M., \& Skrypnek, B. J. (2006). Creating Organizational Conditions that Foster Spirit at Work. Leadership and Organization Development Journal, 27(4), 280-295.

41. Komala, K., \& Ganesh, L. S. (2007). Individual spirituality at work and its relationship with job satisfaction and burnout: An exploratory study among healthcare professionals. The Bus Rev, Cambridge, 7(10): 124-129.

42. Korman, A. K. (1970). Toward an hypothesis of work behavior. Journal of Applied Psychology, 54, 31-41.

43. Korman, A. K. (1971). Organizational achievement, aggression and creativity: Some suggestions toward an integrated theory. Organizational Behavior and Human Performance, 6, 593-613.

44. Korman, A. K. (1976). Hypothesis of work behavior revisited and an extension. Academy of Management Review, 1, 50-63.

45. Krishnakumar, S., \& Neck, C. P. (2002). The "what" and "how" of spirituality in the workplace. Journal of Managerial Psychology, 17(3), 153-164.

46. Laabs, J. J. (1995). Balancing spirituality and work. Personnel Journal, 74(9), 6072.

47. Lewin, K. (1952). Field theory in social science: selected theoretical papers. London: Tavistock.

48. Lewin, K. (1951). Field theory in social science; selected theoretical papers. D. Cartwright (Ed.). New York: Harper \& Row.

49. Maslow, A. H. (1943). A Theory of Human Motivation. Psychological Review, 50, 370-396.

50. Maslow, A. H. (1971). The farther reaches of human nature. New York: Viking.

51. McAllister, D. J., \& Bigley, G. A. (2002). Work context and the (re)definition of self: How organizational care influences organization-based self-esteem. Academy of Management Journal, 45, 894-904.

52. McKnight, R., (1984). Spirituality in the workplace. In: J.D. Adams, (Ed.). Transforming work: A collection of organizational and transformation readings. Alexandria, VA: Miles River Press. 
53. Md. Zabid Abdul Rashid, R.N. Anantharaman \& Jaina Raveendran (1997). Corporate Cultures and Work Values in Dominant Ethic Organizations in Malaysia, Journal of Transnational Management Development,2(4): 60-72

54. Md. Abdul Rashid, M. Sambasivan, \& J. Johari (2003). The Influence of Corporate Culture and Organizational Commitment on Performance, Journal of management development, 22(8), 708-728.

55. Mead, G. H. (1934). The social psychology of George Herbert Mead. A. Strauss (Ed.). Chicago, IL: University of Chicago Press.

56. Mirvis, P. H. (1997). Soul Work' in Organizations. Organization Science 8(2), 193206.

57. Moghali, A.R., \& Maleki tabas, F. (2009).The relationship between organizational culture and organizational creativity in state organizations. Journal of Management Researches, 2, 97-123.

58. Neck, C., \& Milliman, J. (1994). Thought self-leadership: finding spiritual fulfillment in organizational life. Journal of Managerial Psychology, 9 (6), 9-16

59. U.S. Department of Health, Education, and Welfare. (1973). Work in America. Cambridge, MA: MIT Press.

60. Pierce, J. L., Gardner, D. G., Cummings, L. L., \& Dunham, R. B. (1989). Organization-based self-esteem: construct definition, measurement, and validation. Academy of Management Journal, 32 (3), 622-48.

61. Pierce, J.L., \& Gardner, D.G. (2004). "Self-esteem within the work and organizational context: A review of the organization-based self -esteem literature." Journal of Management, 30 (5), 591-622.

62. Phillips, G. M. (2000). Perceived organizational support: An extended model of the mediating and moderating effects of self-structures. Unpublished doctoral dissertation, The University of Akron, Akron, Ohio.

63. Pool, S. W. (2000). Organisational culture and its relationship between job tension in measuring outcomes among business executives. Journal of Management Development, 19 (1), 32-49.

64. Pratt, M. G. (2000). The good, the bad and the ambivalent: managing identification among Amway

65. distributors. Administrative Science Quarterly , 45 , 456-493.

66. Riordan, C. M., Weatherly, E. W., Vandenberg, R. J., \& Self, R. M. (2001). The effects of pre-entry experiences and socialization tactics on newcomer attitudes and turnover. Journal of Managerial Issues, 13 (2), 159-177.

67. Rosen, R. H. (1992). Anatomy of a healthy company. In Renesch, J. (Ed.). New Traditions in Business: Spirit and Leadership in the 21st Century. Berrett-Koehler, San Francisco, CA, 109-22.

68. Saroglou, V., Pichon, I., Trompette, L., Verschueren, M., \& Dernelle, R. (2005). Prosocial behavior and religion: New evidence based on projective measures and peer ratings. Journal for the Scientific Study of Religion, 44 (3), 323-348.

69. Sprecher, S., \& Fehr, B. (2005). Compassionate love for close others and humanity. Journal of Social and Personal Relationships, 2 (5), 629-651.

70. Stace, W. T. (1960). Mysticism and philosophy. Philadelphia: Lippincott. 
71. Tang, T. L., Kim, J. K., \& O’Donald, D. A. (2000). Perceptions of Japanese organizational culture: Employees in non-unionized Japanese-owned and unionized US-owned automobile plants. Journal of Managerial Psychology, 15 (6), 535-559.

72. Trivers, R. L. (1971). The evolution of reciprocal altruism. The Quarterly Review of Biology, 46 (1), 35-57.

73. Van Dyne, L., VandeWalle, D., Kostova, T., \& Cummings, L. L. (2000). Collectivism, propensity to trust and self-esteem as predictors of organizational citizenship in a non-work setting. Journal of Organizational Behavior, 21, 3-23. 


\title{
Summary
}

\section{Organizational Culture and Organization Based Self-Esteem as Predictors of Spirit at work}

\author{
Zeynep Merve Ünal \\ Marmara University, Turkey \\ Tülay Turgut \\ Marmara University, Turkey
}

This study aims to investigate the relationships between organizational cultures, spirit at work, and organization based self-esteem among academicians, and whether organization based self-esteem mediates the relationship between organizational culture and spirit at work. A cross-sectional design was employed, and data were collected through a questionnaire-based survey. Based on the convenience sampling, 417 academicians answered the questionnaire in public and private universities located in Turkey. To analyze the data descriptive statistics, Pearson coefficient, simple and multiple regression analyses were conducted. Feminine organizational culture has more positive contribution on experiencing spirit at work than masculine organizational culture. Moreover, organization based self-esteem does not mediate the relationship between types of organizational culture and spirit at work. Results suggest that organizations hoping to enhance their employee's spirit at work could focalize creating an organizational environment that fosters employee spirit at work. The originality of this paper is that it creates awareness and emphasizes potential contributors that foster an individual's experience of spirit at work.

Keywords: organizational culture, organizational environment, organization based selfesteem, spirituality, spirituality at work 